such associations to develop into proper nationalist movements intent on state control.

Vivian Bickford-Smith

University of Cape Town/Institute of Historical Research, University of London

\title{
The Riches Beneath our Feet: How Mining Shaped Britain
}

Geoff Coyle. Oxford: Oxford University Press, 2010. 288 pp. $£ 20$ (hardback).

The Riches Beneath our Feet is an ambitious study that combines the histories of the three major British mining sectors of coal, metals and quarrying in one volume, from the process of extraction through to the value and common use of many of our native minerals, spanning some 4,500 years.

Geoff Coyle opens his narrative with an exploration of some of the difficulties, such as haulage and rock removal, that early miners had to overcome in order to bring Britain's mineral wealth to the surface; emphasis is placed upon the underground extraction of flint at Grimes Graves in Suffolk. This is followed by a brief examination of Britain's geology and mineral wealth, which leads in to the histories of the individual mining sectors. These include Cornish and West Devon copper and tin mining; lead and zinc mining, which primarily focuses on the Pennine ore field; gold and silver mining, where the author also makes brief reference to semi-precious stones, such as quartz and jet; coal and iron mining; the extraction and production of salt; and the quarrying of granite, stone and slate.

Mining and metallurgical practices specific to each sector are scattered throughout the narrative, whilst the major technological advances are discussed separately. These include the harnessing of water and steam power and the application of gunpowder from the late seventeenth century, and the second phase of mechanisation witnessed primarily by the metal mining sectors with the introduction of mechanical drills and high explosives from the last quarter of the nineteenth century.

By its very nature such a wide ranging coverage results in a snapshot summary of some the key features of each sector, but much is missed. Coyle pays little attention to how the industries shaped their local economies. Despite the exploration of Cornish copper and tin mining, the region's considerable impact beyond Britain in terms of finance, technological advance and manpower is ignored. Similarly there is little discussion on the Cornish miners' fierce individualism and their lack of formal trade unionism compared to the colliers (pp. 112-4) and the men working slate (pp. 138-9). Of greater significance is the neglect of the colliers' role in shaping the nature of British industrial relations. 
Despite the omissions Coyle does place a strong emphasis upon the people such as the contrast he draws between the ten shillings weekly pay of the Welsh copper miners and the industrial landowners, whose concern for the men was minimised by the $₫ 30,000$ per annum they received from their slate mining interests (p. 52), or similarly how hand cutting a facing slab of granite measuring eight by four feet could take 'four months of unremitting labour' (p. 129).

The human story is picked up again towards the end of the volume. Here the author specifically discusses both 'masters and men'. Although mention is made of Lord Penrhyn who struggled to break the quarrymen's union (pp. 138, 204), the mineral owners are portrayed in a positive light, and Coyle details several of the major mining dynasties such as the Fitzwilliam family of Rotherham (pp. 196-7). The story of the miners and their lives is, however, largely taken from George Orwell's The Road to Wigan Pier, and Bert Coombes' These Poor Hands, and the focus is very much on the twentieth century. The industry's safety record is also examined. Coyle highlights the hazards of underground labour in the collieries, such as roof falls, explosions, fires, inrushes of water and the dangers of haulage ropes under high tension. He describes how the prolonged sound of the colliery hooter signalled a serious accident below ground and brought the community to the pit head to wait for news (p. 184). Particular emphasis is given to the surface disaster at Aberfan in the south Wales valleys. A destabilised waste tip slid down Merthyr Mountain on 12 October 1966, destroying everything that stood in its path; a farm, twenty houses and the local school. A total of 144 lives were lost, of which 116 were children (pp. 188-90). Given this emphasis there was a surprisingly limited discussion on the colliers' occupational health.

Equally Coyle pays scant attention to the similar loss of life and bodily damage incurred daily in the metal mining sectors and at the quarry face. The major accidents are described, such as the fire at Snaefall mine on the Isle of Man and the flooding of East Wheal Rose in Cornwall (p. 192). Also included are heroic rescues and survival against all odds, such as Thomas Rowell who endured several days of entombment by eating his tallow candles (p. 190). Yet curiously silicosis, the common cause of death amongst the miners fibroid scarring of lung tissue from the inhalation of fine silica particles, that predisposed the sufferer to secondary tubercular infection, gets only the briefest coverage (pp. 49, 89). This fatal condition reduced the hard rock miners' working life to around eight years following the introduction of mechanised drilling, resulted in an early death and was arguably a driving force behind miners' occupational health reforms in the early twentieth century.

Aside from the strong people perspective, the transformation of the British landscape is a similar consistent theme running through the narrative. Coyle chooses to largely ignore the legacy of degradation and pollution and highlights 
the positive heritage, for example the varied woodlands of the Weald (pp. 161-2), a bequest of the iron industry, the granite architecture of Aberdeen (p. 127), and the siting of the Eden Project in an abandoned china clay quarry (p. 142). The text is also peppered with intriguing 'snippets' of information such as the use of a Cheshire salt mine as an archive facility (p. 226) and the particle physics research into dark energy at Boulby Potash mine (p. 152).

Although Coyle fails to deliver on many themes, he does manage to convey his overall message that mining 'shaped Britain's landscape, material prosperity and way of life' (p. 221). The historical span and broad range of subject material ensures Coyle's two themes of 'longevity and diversity of British mining' are equally conveyed (p. v). The study, however, is unlikely to appeal to a specialist reader. It is not based on original research; it is often speculative, there are no references and the author simply brings together a wide variety of published material that is largely out of date. There are also some factual inaccuracies, for example the provision of two shafts became law in 1862 and not 1872 as stated in the text (pp. 109, 186) and phthisis in the nineteenth-century mining context refers to silicosis with secondary tubercular infection rather than radon induced cancer (p. 52). Nonetheless, Riches Beneath our Feet is an accessible read that will appeal to a non-specialist audience and has the potential to encourage what may be a passing curiosity about mining history into a more determined interest.

\section{Catherine Mills University of Stirling}

\section{An Atlas of the Peninsular War}

Ian Robertson. New Haven: Yale University Press, 2010. xvi +144 pp. $£ 25$ (hardback).

This scholarly work indicates how far we have come since James Wyld's Maps and Plans, Showing the Principal Movements, Battles and Sieges, in which the British Army was Engaged during the War from 1808 to 1814 in the Spanish Peninsula (1840). Based on the surveys by Thomas Mitchell, that was a detailed work dedicated 'to the British Army as a tribute humbly offered to its meritorious services and its high character'. In the keys, the French were referred to as 'the Enemy'. The atlas itself was a source of conflict: Mitchell and his publisher, the cartographer Wyld, quarrelled over money and acknowledgments. ${ }^{3}$ International animosity and entrepreneurial differences were matched by controversies, for

3 T. C. Sargent, 'Thomas Livingston Mitchell and Wyld's Atlas of the Peninsular War, 1808-1814', Cartography, 13 (1984), pp. 257-8. 